\title{
Fiatalkori idiopathiás scoliosis mütéti korrekciójának hatása az állkapocs mozgástartományára
}

\author{
Benke Beáta dr. ${ }^{1}$ - Marada Gyula dr. ${ }^{1}$ - Tunyogi Csapó Miklós dr. ${ }^{2}$ \\ Than Péter dr. ${ }^{2}$ - Radnai Márta dr. ${ }^{1}$
}

Pécsi Tudományegyetem, Klinikai Központ, ${ }^{1}$ Fogászati és Szájsebészeti Klinika,

${ }^{2}$ Ortopédiai Klinika, Pécs

\begin{abstract}
Anatómiai és funkcionális szempontból a stomatognath rendszer szoros kapcsolatban van a gerincoszlop nyaki csigolyáival. A köztük lévő neuromuscularis kapcsolat miatt ez fontos határterület fogorvosok és ortopéd orvosok számára. Esetismertetésünkben bemutatjuk, hogy milyen módon változott az állkapocsízület funkciója egy idiopathiás scoliosisos páciens ortopédiai mútéti korrekciójának hatására. A 15 éves fiatalkori idiopathiás scoliosisos nőbeteg gerincferdülésének korrekciójára 2016-ban került sor. A mútétet megelőző napon és 10 hónappal később funkcióanalitikai vizsgálatot végeztünk ultrahangalapú jelzőkészülékkel. A mozgástartomány-vizsgálat jelentős javulást mutatott. A szájnyitáskor korábban fennálló $8 \mathrm{~mm}$-es jobbra deviáció $2 \mathrm{~mm}$-re csökkent. A bal oldalmozgáskor látott blokk a 10 hónapos kontroll során teljesen szabaddá vált, illetve az eredeti aszimmetrikus protrusio majdnem teljesen szimmetrikus lett. Vizsgálatunk eredményeit értékelve elmondhatjuk, hogy a mandibula mozgásai, deviációja, valamint a mozgástartományt leíró értékek is lényegesen javultak tíz hónappal a mútét után. Tekintettel arra, hogy a páciens temporomandibularis ízületi diszfunkciós kezelést nem kapott, feltételezzük, hogy kapcsolat volt a gerincoszlop és az állkapocsízület funkciója között.
\end{abstract}

Orv Hetil. 2018; 159(50): 2144-2149.

Kulcsszavak: scoliosis, temporomandibularis ízületi diszfunkció, állkapocsízületi mozgástartomány

\section{Comparing the function of the temporomandibular joint before and after surgical treatment in a young patient with idiopathic scoliosis}

\section{Case presentation}

From an anatomic and functional point of view, the stomatognathic system and the upper cervical spine are closely connected. Together with the complex neuromuscular relationships, this generates an important field of cooperation between dentists and orthopedics. The aim of this case report was to demonstrate the improvements of temporomandibular joint (TMJ) function after orthopedic surgery in case of a patient with idiopathic scoliosis. A 15 -year-old female patient who had adolescent idiopathic scoliosis was surgically treated in 2016. Functional analyses of the TMJ were performed before the day of the operation and 10 months after the surgery. For detection, an ultrasound-based testing machine was used. The analyses of the data showed that almost all ranges of motions (ROM) were improved. The deviation to the right side was reduced from $8 \mathrm{~mm}$ to $2 \mathrm{~mm}$ during mouth opening. The patient had limited left lateral movement before the operation, however, after 10 months following the operation, there were free motions towards both sides. The originally asymmetrical protrusion became almost completely symmetrical. Regarding the functions of the TMJ, the surgery was successful; this in itself had a beneficial effect on the range and the path of the mandibular movements without any other treatment. These improved functions are indirect evidences for the connection of the function of the spine and TMJ.

Keywords: scoliosis, temporomandibular joint dysfunction, range of motions

Benke B, Marada Gy, Tunyogi Csapó M, Than P, Radnai M. [Comparing the function of the temporomandibular joint before and after surgical treatment in a young patient with idiopathic scoliosis. Case presentation]. Orv Hetil. 2018; 159(50): 2144-2149.

(Beérkezett: 2018. június 12; elfogadva: 2018. július 12.) 


\section{Rövidítések}

$\mathrm{AP}=$ anteroposterior; $\mathrm{KK}=$ Klinikai Központ; $\mathrm{PTE}=$ Pécsi Tudományegyetem; TMJ/TMI = (temporomandibular joint $)$ temporomandibularis ízület

A stomatognath rendszer egészséges múködése során az állkapocsízület, az orofacialis izomzat, a fogak és azok támasztószövetei egységes rendszert alkotnak [1]. Amennyiben valamelyik egység, azok innervációja vagy az okklúzió károsodik, temporomandibularis ízületi diszfunkció kialakulására számíthatunk [2].

A gerincoszlopnak fontos szerepe van az egyenes testtartás biztosításában, segít a harmonikus mozgásban. Bármilyen, a gerincoszlop épségét károsító tényező következtében háti, mellkasi és végtagi deformitások alakulhatnak ki [3]. Mivel anatómiai és funkcionális szempontból a stomatognath rendszer szoros kapcsolatban van a gerincoszlop nyaki csigolyáival, mind az állkapocsízületet, mind a gerincoszlopot érintő elváltozások kölcsönösen hatással vannak egymásra.

A nyaki gerinc a mozgások koponyára való átviteléért felelős, és hidat biztosít a fej, a törzs és a felső végtagok között [4]. Amennyiben az első nyakcsigolyának, az atlasnak megváltozik a helyzete, úgy ez a billenés az egész gerincre hatással van, instabillá válik a nyaki gerincszakasz, és a nyaki izomzat funkciója is megváltozik. Ennek eredményeképpen a gerincet érő terhelés egyenlőtlenül oszlik meg, ami hatással lesz a gerinc többi szakaszára is, majd olyan deformitáshoz vezethet, amelyből később scoliosis is kialakulhat [5]. Ezenkívül az antagonista fogak pozíciója is módosulhat, malocclusio (okklúziós rendellenesség) alakulhat ki, mely az állkapocsízület mozgástartományát is módosítja.

A bemutatott eset kapcsán egy 15 éves, súlyos kettős scoliosisban szenvedő leány kombinált ortopédiai kezelésének a stomatognath rendszerre gyakorolt hatását kívánjuk bemutatni. Ezen összefüggések klinikai jelentőségét matematikai paraméterekkel terveztük alátámasztani.

\section{Módszer}

A PTE KK Ortopédiai Klinikáján idiopathiás scoliosis miatt 2016. szeptemberben operált páciens állkapocsmozgástartományának mérését végeztük prospektív klinikai vizsgálatban (kutatásetikai engedélyszám: 5831) az operáció napját megelőző napon, illetve a mütét után 10 hónappal. Az ortopédai mútét eredményeinek kontrollálása végett egy-egy AP és oldalirányú gerinc-röntgenfelvétel is készült a két fogászati méréssel azonos időpontban.

A stomatologiai vizsgálat során a Jaw Motion Analysis (JMA) System és a hozzá tartozó WinJaw szoftver segítségével (Zebris Medical GmbH, Isny im Allgäu, Németország) funkcióanalitikai vizsgálatokat végeztünk [6].

A szoftver felhasználási területe sokoldalú, a JMA System összegzi az egyén alsó állcsontjának mozgásait, ami

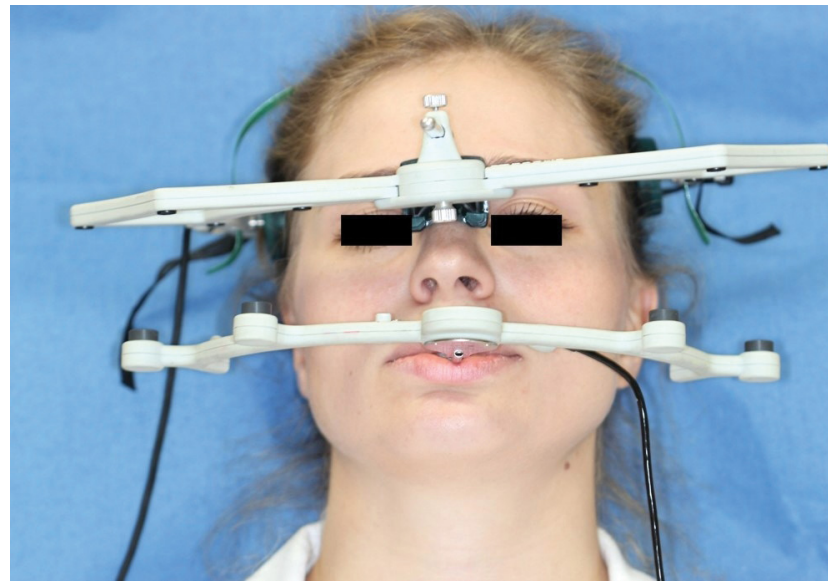

1. ábra

A fejre rögzített keret és az állkapocshoz rögzített ultrahangjeladó

később akár egy esetleges fogpótlás vagy harapásemelő sín elkészítéséhez szükséges lehet [7].

A vizsgálat menete a következő volt: miután a rendszerrel regisztráltuk az állkapocs pozícióját, a páciensnek különböző, előre meghatározott: bemutatott és begyakorolt mozdulatsorokat (protrusio - az állkapocs előremozdítása; laterotrusio - az állkapocs oldalra mozdítása) kellett végeznie az állkapcsával, amelyeket a szoftver folyamatosan dokumentált. Az elektromos pozícióanalízis jól modellezte a preoperatív és a posztoperatív mérések közti különbséget.

A vizsgálat noninvazív, ultrahangimpulzusokon alapszik, az alsó fogsorhoz ultrahangalapú jeladót rögzítünk. Az állkapocsmozgások során változik az ultrahang jelintenzitása, amit a fejre rögzített tartozék detektál, majd ezekből az értékekből a szoftver háromdimenziós képet alkot a mandibula mozgásairól (1. ábra). Ahhoz, hogy a szoftver pontos képet tudjon alkotni, szükségünk van előzőleg beállított referenciapontokra az arcon. Ilyen referenciapont a tragus és a nervus infraorbitalis kilépési helye a szemüreg alatt. A mérésekhez használt WinJaw nevü program a Windows 98 (Microsoft, Redmond, WA, Amerikai Egyesült Államok [USA]) vagy az újabb operációs rendszereket támogatja. A szoftverben létrehozható adatbank, mely a páciensek adatait és az egyes mérések eredményeit tartalmazza, harmadik személy számára nem férhető hozzá. A feldolgozás befejeztével a mérések a Record Explorer nevü programmal (Meridium Inc., Roanoke, VA, USA) újra megnyithatók, konfigurálhatók és exportálhatók.

A betegnek az alábbi mozdulatsort kellett végrehajtania és háromszor megismételnie, majd a mozdulatok kezdetén és azok befejeztével is az általa kényelmesnek talált, habituális pozícióba vitte vissza mandibuláját:

- maximális szájnyitás előretolt mandibulával;

- maximális szájnyitás;

- a mandibula mindkét oldalra való maximális laterotrusiója; 


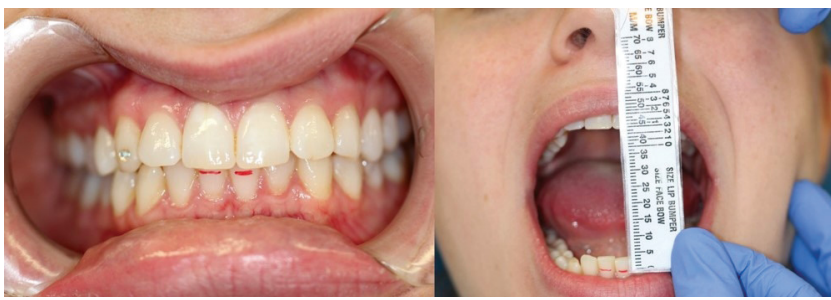

2. ábra | Maximális szájnyitás standard mérése

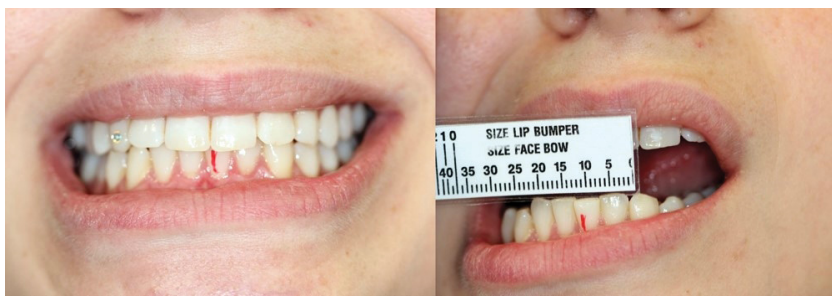

3. ábra

| Oldalmozgás standard mérése

- habituális mandibulapozíció, a mandibula protrusiója, maximális szájnyitás, habituális mandibulapozíció;

- habituális mandibulapozíció, a mandibula mindkét oldalra való maximális laterotrusiója, maximális szájnyitás, habituális mandibulapozíció.

Ezen mandibulamozgások átlagos értékei egészséges páciensek esetén a következők: szájnyitás $40-60 \mathrm{~mm}$, oldalra mozdítás (laterotrusio) $10 \mathrm{~mm}$ jobbra és balra is, előremozdítás (protrusio) $9 \mathrm{~mm}$ [8].

A standard méréseket vonalzóval végezzük, szájnyitáskor interincisalis (az alsó és a felső metszőfogak élei közötti) távolságot detektálunk (2. ábra), melyhez hozzáadódik a metszőfogi 'overbite' (vertikális túlharapás), míg oldalmozgáskor a felső nagymetsző́k által meghatározott középvonalhoz viszonyítunk (3. ábra) $[9,10]$. Ehhez a technikához képest a WinJaw programmal a mozgáspályák dinamikája is jellemezhető, diagnosztikai segítséget nyújtva ezáltal az esetleges állkapocsízületi betegségekről.

\section{Eredmények}

Az alábbiakban egy páciensen végzett funkcióanalitikai vizsgálatsorozat eredményeit mutatjuk be. A 15 éves nőbetegnél kettős, $60^{\circ}$-os Cobb-szögú jobbra konvex thoracalis és balra konvex $58^{\circ}$-os lumbalis görbülettel járó scoliosist diagnosztizáltak (4. ábra). A páciens súlyos fokú fiatalkori idiopathiás scoliosisának korrekciójára a PTE KK Ortopédiai Klinikáján került sor (5. ábra) [11, 12]. A mútét során antibiotikus profilaxisban CotrelDubousset szerinti korrekciós posterolateralis spondylodesist végeztek a Th III-as és az L IV-es csigolya között.

A háti III. és ágyéki V. csigolya között ejtett háti középvonali bőrmetszésből végzett feltárásból, hagyományos transpedicularis csavarokhoz rögzített, megfeleló alakban meghajlított korrekciós rudakkal végzett scoliosiskorrekciós beavatkozás történt, a görbület konkáv

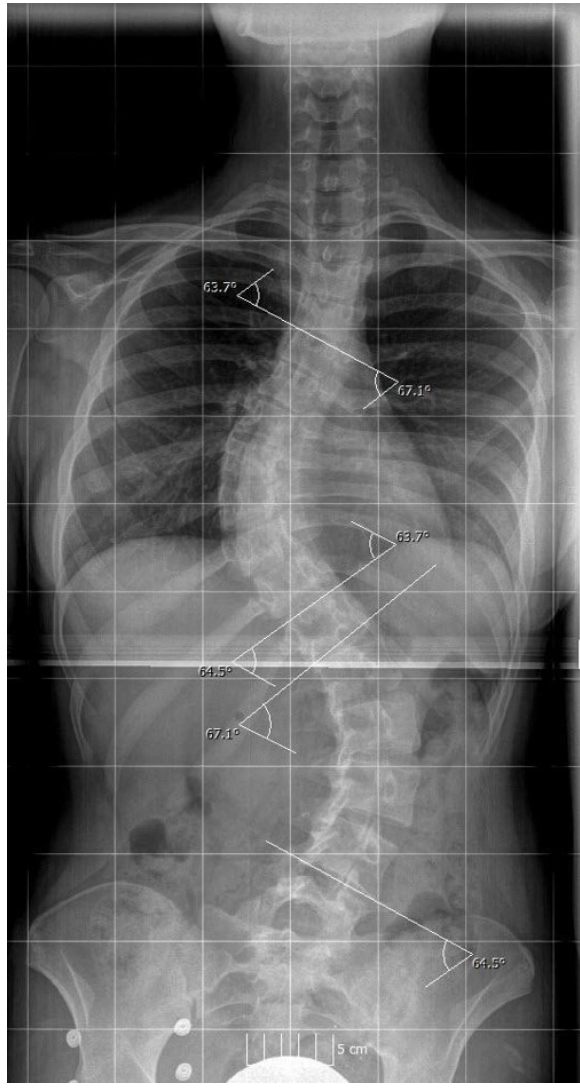

4. ábra | Anteroposterior irányú preoperatív röntgenfelvétel

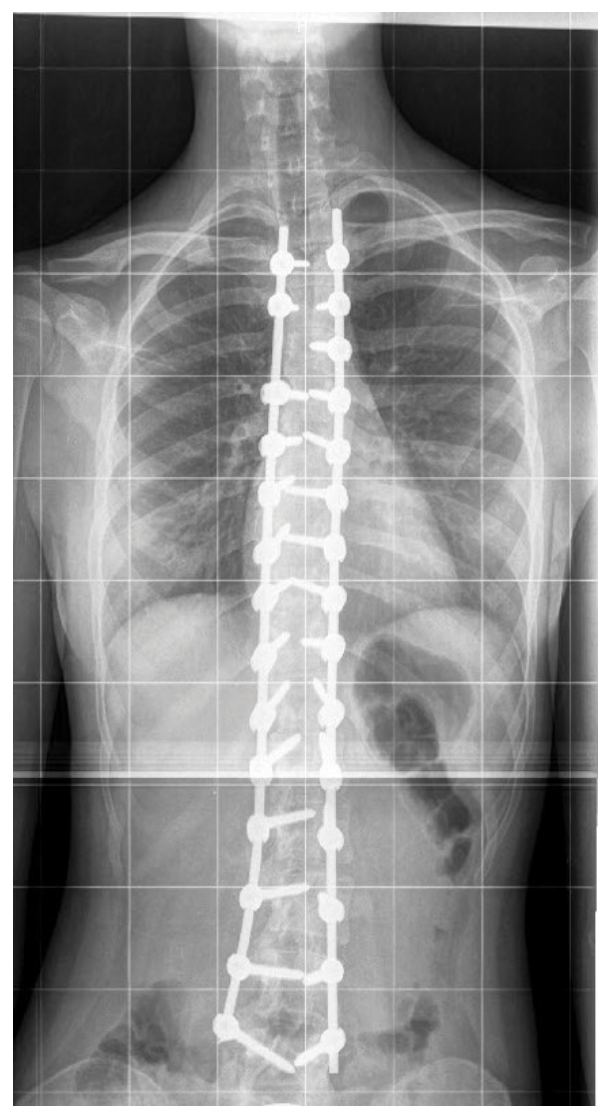

5. ábra $\mid$ Anteroposterior irányú posztoperatív röntgenfelvétel 
oldalán disztrakcióval, a konvex oldalon kompresszióval. A hagyományos korrekciós technika kivitelezése és a kifejezetten merev görbület felszabadítása érdekében, megelőzően minden egyes érintett gerincszegmentumban a háti szakasz kisízületeinek Ponte, illetve az ágyéki szakasz kisízületeinek Smith-Petersen szerinti osteotomiákat is végeztek. A tervezett korrekciós állapot elérése után a laminák környezetét auto- és allograft csontőrleménnyel töltötték fel.

A két röntgenképen jól össze lehet hasonlítani a preoperatív és posztoperatív állapotot. Mindkét felvételen látható, hogy a bal váll magasabban helyezkedik el a jobbhoz képest, valamint a nyaki gerinc is enyhén jobbra deviál. Mindkét elváltozás a gerincferdülést kompenzáló mechanizmusokra vezethető vissza. Az operáció utáni 10 hónapos regenerációs időszak után egyértelműen megállapítható, hogy a gerincoszlop egyenesebb lett, a nyaki gerinc deviációja is enyhén minimalizálódott, a háti kyphosis elsimult, a lumbalis lordosis megtartott. Összehasonlítva a korábbi röntgenfelvételekkel, látható, hogy a jobbra convex thoracalis és balra convex lumbalis lordosis jelentősen mérséklődött.

A fiatalkori idiopathiás scoliosis alapvető jellegzetessége, hogy serdülőkorban még az extrém görbületek sem fájdalmasak, a betegek panaszmentesek, nagyfokú mellkasdeformitással járó esetekben az egyedüli panasz a fáradékonyság és a terhelésre jelentkező vagy a későbbiekben már nyugalomban is fellépő dyspnoe és emésztési zavar.

A scoliosis konzervatív kezelése, valamint mütéti előkészítése során sem gyulladáscsökkentő, sem izomrelaxáns gyógyszerek nem javasoltak. A korai posztoperatív szakban a mútéti korrekció során megnyújtott izomfeszülés okozhat fájdalmat, mely miatt a mütét után átlagosan 2-3 hétig szóba jön izomrelaxáció, és természetesen a fájdalomcsillapítók teljes spektruma használatos.

$\mathrm{Az}$ előzetes preoperatív klinikai vizsgálatok során elvégzett fogorvosi vizsgálat eredményei a következők voltak [13]. Angle I. típusú normálocclusiót találtunk, a páciensnek korlátozott állkapocsmozgása volt (szájnyitás: $31 \mathrm{~mm}$, oldalmozgás balra: $0 \mathrm{~mm}$, oldalmozgás jobbra: $10 \mathrm{~mm}$, előremozdítás: $7 \mathrm{~mm}$ ), de craniomandibularis diszfunkcióra utaló egyéb primer jelek - ízületi hangjelenség és izom-, illetve ízületi fájdalom - sem voltak jellemzők [14]. A rágóizmok (musculus masseter, m. temporalis, m. pterygoideus medialis, m. pterygoideus lateralis) tapintásos vizsgálata során sem a bal, sem a jobb oldalon nem jelzett fájdalmat a páciens.

Tíz hónappal a scoliosiskorrekciós mútétet követően a mérések újbóli elvégzése után a preoperatív és a posztoperatív eredmények összehasonlítása történt.

Maximális szájnyitáskor preoperatívan a normális, deviáció nélküli szájnyitáshoz képest $8 \mathrm{~mm}$-es jobbra irányuló deviációt (a középvonaltól való eltérést) figyeltünk meg, amely a posztoperatív időszak 10. hónapjában már csak $2 \mathrm{~mm}$ volt. A maximális szájnyitás mútét előtt és

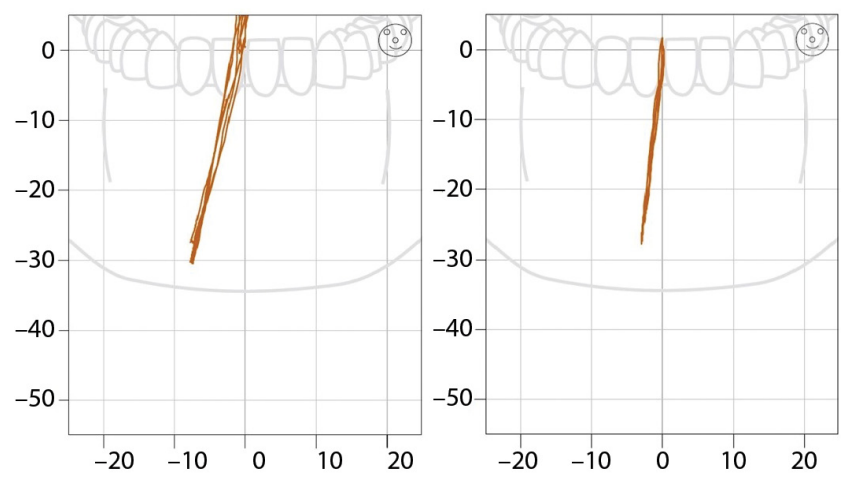
\begin{tabular}{l|l} 
6. ábra & $\begin{array}{l}\text { A szájnyitás frontális síkban történő mérése; balra a preoperatív, } \\
\text { jobbra a posztoperatív felvétel }\end{array}$
\end{tabular}

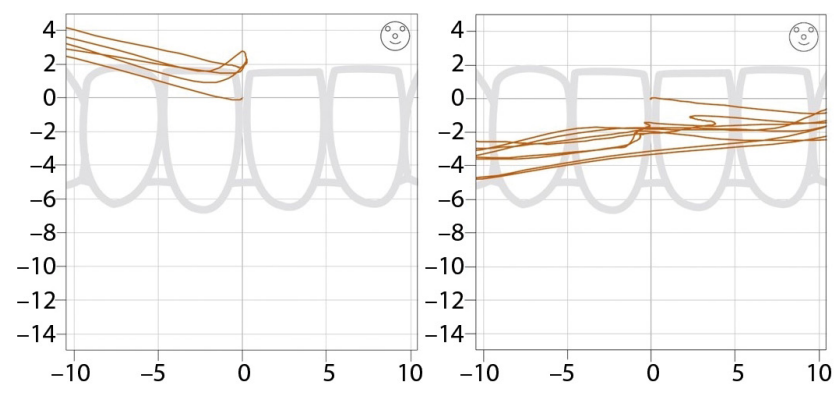

7. ábra $\quad$ Az oldalmozgások frontális síkban történő mérése; balra a pre operatív, jobbra a posztoperatív felvétel

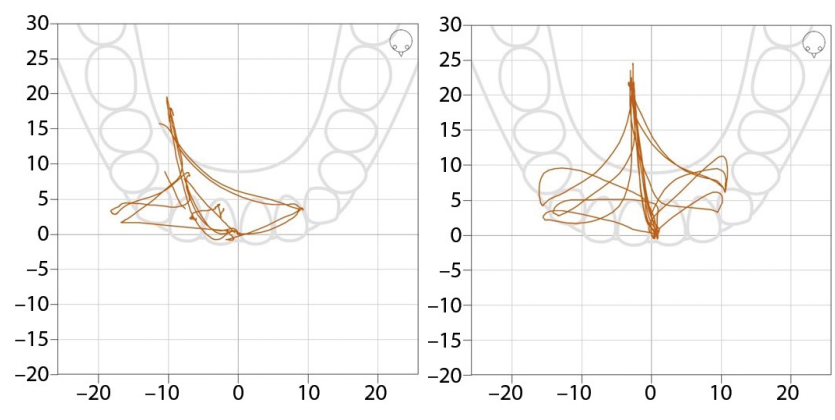

\begin{tabular}{l|l} 
8. ábra & Kombinált pro- és laterotrusiós mozgás a horizontális síkban:
\end{tabular} balra a preoperatív, jobbra a posztoperatív felvétel

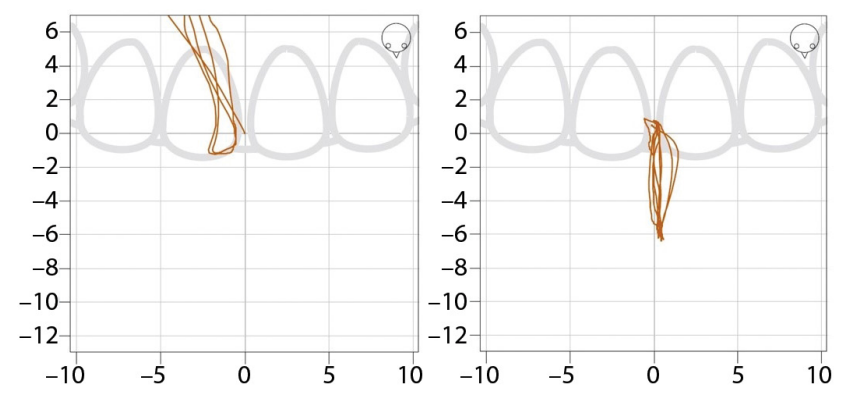

9. ábra $\quad$ A mandibula protrusiós mozgásai a horizontális síkban; balra a preoperatív, jobbra a posztoperatív felvétel 
után is $31 \mathrm{~mm}$ volt, amely még $10 \mathrm{~mm}$-rel a normáltartományon kívül helyezkedik el (6. ábra).

A laterotrusiós mozgások vizsgálata során preoperatívan erősen korlátozott mozgásokat észleltünk: csak jobbra történt laterotrusio, a bal oldalra blokkolt volt a mozgás. A mútét után 10 hónappal ez a mozgástartomány-beszúkü̈lés megszűnt, és mindkét irányban normális 10-10 mm-es értékeket mértünk (7. ábra).

$\mathrm{Az}$ alsó fogsor metszőfogai laterotrusio és protrusio során jellegzetes mintázatot írnak le, ennek a vizsgálatával elemezhetjük az alsó állkapocs szabad mozgásait is. Normálértéknek - latero- és protrusio során is - a 10 , illetve $9 \mathrm{~mm}$-es értéket tekintjük, a $7 \mathrm{~mm}$-es érték alatti elmozdulást diszfunkciónak tekintjük. A sikeres korrekciós mútét után a páciens képes volt az állkapcsát balra is elmozdítani, és a jobb oldalra $1 \mathrm{~cm}$-rel deviáló protrusio is normalizálódott (8. ábra). A mütét után 10 hónappal egyértelmú javulást figyeltünk meg, a dinamikus occlusio során az alsó állkapocs mozgása és mozgástartománya is a normálértékek felé közeledett.

A protrusiós mozgások során is egyértelmû javulást regisztráltunk. A preoperatív időszakban nagymértékben retrudáló (dorsalis irányba mozduló), jobbra deviáló mandibulamozgásokat észleltünk, és csak minimális protrudáló mozgást mértünk, majd a posztoperatív időszakban mind a retrusiós, mind a protrusiós mozgás során mért értékek normalizálódtak, és a középvonali eltérés is megszűnt (9. ábra).

\section{Megbeszélés}

A temporomandibularis ízületi diszfunkcióval összefüggésbe hozható betegségek (például rheumatoid arthritis) mellett egyre inkább előtérbe kerül a gerincoszlop helyes görbületének fontossága [15].

A scoliosisos páciensek egy részénél megfigyelhető állcsonthelyzeti rendellenesség jól mutatja a rágóizmok funkcionalitásának jelentőségét [16]. A két arcfélen eltérően múködő izomaktivitás az oka lehet állkapocsízületi elváltozásnak, ami saját esetünkben is látható [17]. Speciális fizioterápiás gyakorlatokkal a megfelelő rágóizomfunkciót javítva további sikert érhetünk el [18]. Vizsgálatunk eredményeit értékelve elmondhatjuk, hogy a mandibula mozgásai, deviációja, valamint a mozgástartományt leíró értékek is lényegesen javultak tíz hónappal a mütét után. Tekintettel arra, hogy a páciens TMI-diszfunkciós kezelést nem kapott, feltételezzük, hogy kapcsolat volt az idiopathiás scoliosis és a mandibula mozgásai között [19]. A páciens gyógyszeres terápiát a temporomandibularis ízületi problémára nem kapott, csak a scoliosiskorrekciós mütét kéthetes posztoperatív szakaszában részesült nemszteroid gyulladáscsökkentő és izomrelaxáns terápiában, és mivel a mérés 10 hónappal az ortopédiai beavatkozás után volt, a mozgástartomány-javulást inkább a sikeres mütétnek tulajdoníthatjuk.
A kompenzációs mechanizmusok révén a nyaki gerincszakasz az atlason keresztül összeköttetésben van az egész stomatognath rendszerrel, és indirekt módon hat az állkapocsízületre és a hozzá tartozó anatómiai egységekre. A fiatalkori idiopathiás scoliosis eredményes mütéti korrekciója kiemelten hatott az állkapocsízületre: objektíven mérhető, szabad mozgásokat eredményezett, a kóros elmozdulások javultak, így egy későbbi funkcionális zavar kialakulását is megakadályozta, nem utolsósorban a késóbbi vizsgálatok során a tárolt adatok egymással összehasonlíthatók lesznek [20].

Anyagi támogatás: A közlemény megírása anyagi támogatásban nem részesült.

Szerzői munkamegosztás: B. B.: A hipotézis kidolgozása, a kézirat megszövegezése. M. Gy., T. Cs. M.: Az adatok elemzése. T. P.: A hipotézis kidolgozása. R. M.: A hipotézis kidolgozása, a kézirat végső korrekciója. A cikk végleges változatát valamennyi szerző elolvasta és jóváhagyta.

Érdekeltségek: A szerzőknek nincsenek érdekeltségeik.

\section{Irodalom}

[1] Fricton JR, Schiffman EL. The craniomandibular index: validity. J Prosthet Dent. 1987; 58: 222-228.

[2] Berretin-Felix G, Genaro KF, Trindade IE, et al. Masticatory function in temporomandibular dysfunction patients: electromyographic evaluation. J Appl Oral Sci. 2005; 13: 360-365.

[3] Kendall FP, McCreary EK, Provance PG, et al. Muscles: testing and function with the posture and pain. 5 th edn. Lippincott Williams \& Wilkins, Baltimore, MD, 2005; pp. 60-63.

[4] Floman Y. Thoracic scoliosis and resticted head motion: a new syndrome? A report of six cases. Eur Spine J. 1998; 7: 155-157.

[5] Magee DJ. Orthopedic physical assessment. 6th edn. Elsevier, Oxford, 2008; pp 2-68.

[6] https://www.zebris.de

[7] Lehmann KM, Hellwig, E. Zahnärztliche Propädeutik. Elsevier, München, 2009; pp. 59-72.

[8] Radnai M. Movements of the mandible. In: Radnai M. (ed.) Odontology and gnathology. [Az állkapocs elmozdulásai. In: Radnai M. (szerk.) Odontológia és gnatológia.] Medicina Könyvkiadó, Budapest, 2013; pp. 97-116. [Hungarian]

[9] McNamara JA Jr, Seligman DA, Okeson JP. Occlusion, orthodontic treatment, and temporomandibular disorders: a review. J Orofac Pain 1995; 9: 73-90.

[10] Walker N, Bohannon RW, Cameron D. Discriminant validity of temporomandibular joint range of motion measurements obtained with a ruler. J Orthop Sports Phys Ther. 2000; 30: 484492.

[11] Janicki JA, Alman B. Scoliosis: Review of diagnosis and treatment. Paediatr Child Health 2007; 12: 771-776.

[12] Huang SC. Cut-off point of the scoliometer in school scoliosis screening. Spine 1997; 22: 1985-1989.

[13] Strub JR, Kern M, Türp JC, et al. Curriculum Prothetik. Quintessence Publishing, Berlin, 2011; pp. 67-71.

[14] Okeson JP. Management of temporomandibular disorders and occlusion. Elsevier, St. Louis, MO, 2012; pp. 102-128, $164-$ 215.

[15] Chin Jen Sem JP, van der Leeden M, Visscher CM, et al. Prevalence, course, and associated factors of pain in the temporoman- 
dibular joint in early rheumatoid arthritis: results of a longitudinal cohort study. J Oral Facial Pain Headache 2017; 31 233-239.

[16] Ikemitsu H, Zeze R, Yuasa K, et al. The relationship between jaw deformity and scoliosis. Oral Radiol. 2006; 22: 14-17.

[17] Friedman MH, Weisberg J. Application of orthopedic principles in evaluation of the temporomandibular joint. Phys Ther. 1982; 62: 597-603.

[18] Park Y, Bae Y. Change of range of motion of the temporomandibular joint after correction of mild scoliosis. J Phys Ther Sci. 2014; 26: 1157-1160.

[19] Kiss G, Pácz M, Kiss P. Craniomandibular disorder/dysfunction. Characteristics and disorders of the masticatory organ. [Cranio- mandibularis diszfunkció. A rágószerv sajátosságai és múködési zavarai.] Orv Hetil. 2015; 156: 122-134. [Hungarian]

[20] Illés ST. Reckoning: assessment of a 21 -year activity in spine surgery. [Számvetés: 21 éves gerincsebészeti tevékenység mérlege.] Orv Hetil. 2015; 156: 598-607. [Hungarian]

(Benke Beáta dr., Pécs, Dischka Győző u. 5., 7621 e-mail: benke.beata@pte.hu)

\section{PÁLYÁZAT}

A Prof. Dr. Romics László Akadémikus Emlékére Alapítvány pályázatot hirdet Magyarországon dolgozó, magyar állampolgárságú, 40 éven aluli orvosok és orvosbiológiai kutatással foglalkozó személyek számára. A nyertes pályázó(k) között 500000 Ft alapítványi adomány kerül kiosztásra.

A pályázat célja: a klinikai gyógyítás vagy orvosi tudományos kutatás területén dolgozók kiemelkedő tudományos tevékenységének elismerése.

Előnyt élveznek azok a pályázók, akik az alapítvány névadójának munkásságát folytatva cardiovascularis és anyagcsere-betegségek területéről nyújtanak be pályázatot.

A pályázat benyújtásának határideje: 2019. január 31. (elbírálásának határideje: 2019. április 30.)

A pályázatot a palyazat@romicsalapitvany.hu e-mail címre pdf formátumban kell benyújtani.

A pályázatot természetes személy, saját nevében, magyar nyelven nyújthatja be, a pályázati anyag ábrák nélkül maximum 15000 leütés (karakter) terjedelmü lehet. A pályázathoz mellékelni kell egy rövid szakmai életrajzot a születési év megjelölésével.

A pályázat benyújtását saját kézzel aláírt és dátummal ellátott levélben kell bejelenteni az alapítvány titkárának címezve (a borítékra írandó cím: dr. Dudás Márta, 1461 Budapest, Pf 62.) könyvelt (ajánlott) küldeményben, mert ezen bejelentés alapján válik hitelessé a pályázat. A pályázatot nyomtatott formában nem kell mellékelni.

Az alapítvány adatairól, működéséről a www.romicsalapitvany.hu honlapon található információ. 